\title{
ТЕХНОЛОГИЯ «ПЕРЕВЕРНУТЫЙ КЛАСС» КАК СРЕДСТВО ОПТИМИЗАЦИИ САМОСТОЯТЕЛЬНОЙ РАБОТЫ ШКОЛЬНИКОВ
}

\section{Щербинская А.А.}

Балтийский федеральный университет

им. Иммануила Канта, г. Калининград, Калининградская область, Российская Федерация

В статье рассматривается вопрос о том, как необходимо преобразовать урок в циелях развития самостоятельности учеников, приводятся теоретические основы методики обучения «Перевернутого класса».

Ключевые слова: перевернутый класс; перевернутое обучение; самостоятельность; самостоятельная работа; умения самостоятельной работьл.

\section{TECHNOLOGY «INVERTED CLASS» AS A MEANS OF OPTIMIZING THE INDEPENDENT WORK OF STUDENTS}

\section{Scherbinskaya A.A.}

Immanuel Kant Baltic Federal University, Kaliningrad, Kaliningrad region, Russian Federation

The article discusses the question of how it is necessary to transform a lesson in order to develop student autonomy, provides the theoretical basis for the Inverted Class teaching methodology.

Keywords: Inverted class; inverted learning; independence; independent work; skills of independent work.

В соответствии с актуальными ФГОС школьного образования, образование должно быть ориентировано, в первую очередь, на раз- 
витие определенных компетенций и самостоятельности учеников.

Значительное влияние на образовательный процесс в школе оказали компьютеризация образовательных учреждений и развитие современных ИКТ. Нередко в современной школе учащиеся получают знания, мало соответствующие требованиям, которые предъявляет сегодня общество к выпускникам школ.

Из-за недостатка классного времени и, практически, отсутствия личного общения между учителем и учеником в рамках учебного времени, появляется потребность в оптимизации процесса обучения посредством пересмотра традиционной модели урока и преобразования его классической структуры. Сегодня перед учителями стоит задача, в том, как перестроить классное занятие таким образом, чтобы можно было максимально продуктивно использовать время урока. Чтобы решить данную проблему, создателями модели «Перевернутый класс» было принято решение полностью изменить структуру урока: поменять местами привычные части учебного процесса (домашнюю и классную работу) так, чтобы знакомство с новым материалом происходило дома, а практические задания, обсуждения и закрепление материала осуществлялись непосредственно во время урока.

Flipped classroom или «перевёрнутый класс» - это технология обучения, которая является одним из видов так называемого «смешанного обучения» (Blendeed learning). Данная модель урока предполагает самостоятельное усвоение основного или дополнительного учебного материала дома при просмотре видео-лекций, чтении учебной литературы, прохождении учебных тестов на начальное усвоение темы, при этом аудиторное время посвящается анализу проблемных вопросов теоретической части, а также выполнению практических и творческих заданий под наблюдением педагога [3].

Очевидно, что, программа в старшей школе насыщена учебным материалом и предполагает изучение информатики в течение одного часа в неделю. За отведенное время систематизировать необходимый объем информации и сформировать стойкие практические на- 
выки у учеников, используя традиционные средства классической педагогики, трудно, а нередко и невозможно.

Для выполнения действующих программ по информатики приходится искать пути увеличения продуктивности проведения уроков. Предлагаемое «перевернутое обучение», в частности, предусматривает отказ от таких малоэффективных в условиях ограниченного времени приемов, как:

1) выступление учеников возле доски;

2) фронтальный опрос;

3) диктовка конспектов;

4) просмотр длительных учебных фильмов и презентаций.

Вместо этого технология «перевернутый класс» активирует элементы педагогики сотрудничества: учитель выступает в роли партнера и консультанта. Ученики овладевают учебным материалом, в значительной мере при самообучении, что на наш взгляд, способствует развитию познавательной активности и самостоятельности [1].

В настоящее время сетевое сообщество «перевернутых педагогов» насчитывает около 16000 человек. Нами был проведен эксперимент с применением «перевернутого обучения», который показал, что такая модель урока формирует умения самостоятельной работы учеников.

В процессе самостоятельного обучения информатики у учеников формируются такие умения как:

1) самостоятельно планировать свою деятельность;

2) самостоятельно работать с учебной и дополнительной литературой;

3) извлекать наиболее значимую информацию из текста, выделять главное

4) самостоятельно приобретать и углублять знания;

5) анализировать, сопоставлять;

6) повторять изученный материал и закреплять уже изученный;

7) многократно выполнять определённые действия, или виды деятельности, имеющее цель их усвоение, опирающееся на 
понимание этой цели и общей программы действия и сопровождающееся сознательным контролем и корректировкой;

8) четко и ясно излагать свои мысли, учитывать индивидуальные особенности своей умственной деятельности и физиологические возможности;

9) самостоятельно сравнивать, доказывать, делать выводы, формулировать вопросы;

10) самостоятельно систематизировать материал.

Развитие умений самостоятельной работы является практически основной целью обучения. Ведь самостоятельность - одно из главных качество учащихся и важнейшее условие их обучения. Очевидно, что чем выше уровень самостоятельности учеников, тем эффективнее их продвижение в учебной деятельности [2].

Таким образом, технология «перевернутое обучение» мотивирует учеников на самостоятельную деятельность, что в свою очередь, способствует формированию самостоятельности.

\section{Список литературы}

1. Алексеева Е.Е. Роль математической компетентности в обеспечении качества образования // Современные исследования социальных проблем (электронный научный журнал). 2017. Т. 8. № 11-2. C. $12-17$.

2. Алексеева Е.Е. Креативное содержание как средство формирования креативной компетенции студентов на занятиях высшей математики // Наука Красноярья. 2014. Т. 3. № 4. С. 39-49.

3. Мирошникова Н.Н. «Перевернутый класс» - инновационная модель в обучении иностранным языкам в высшей школе. Чебоксары: ЦНС «Интерактив плюс», 2016.

4. Чебурина О.В. Формирование умений самостоятельной работы на уроках информатики с использованием современных информационных технологий [Электронный ресурc]. URL: https://cyberleninka. $\mathrm{ru} /$ article/n/formirovanie-umeniy-samostoyatelnoy-raboty-na-urokah-informatiki-s-ispolzovaniem-sovremennyh-informatsionnyh-tehnologiy 


\section{References}

1. Alekseeva E.E. Rol' matematicheskoy kompetentnosti v obespechenii ka-chestva obrazovaniya // Sovremennye issledovaniya sotsial'nykh problem (elektronnyy nauchnyy zhurnal). 2017. T. 8. № 11-2. S. 12-17.

2. Alekseeva E.E. Kreativnoe soderzhanie kak sredstvo formirovaniya kreativnoy kompetentsii studentov na zanyatiyakh vysshey matematiki // Nauka Krasnoyar'ya. 2014. T. 3. № 4. S. 39-49.

3. Miroshnikova N.N. «Perevernutyy klass» - innovatsionnaya model' v obuchenii inostrannym yazykam v vysshey shkole. Cheboksary: TsNS «Interaktiv plyus», 2016.

4. Cheburina O.V. Formirovanie umeniy samostoyatel'noy raboty na urokakh informatiki s ispol'zovaniem sovremennykh informatsionnykh tekhnologiy [Elektronnyy resurs]. URL: https://cyberleninka.ru/article/n/formirovanie-umeniy-samostoyatelnoy-raboty-na-urokah-informatiki-s-ispolzovaniem-sovremennyh-informatsionnyh-tehnologiy 